\title{
Improving Quality of Pharmacoeconomic Studies: Guidelines for Avoiding Bias
}

\author{
Akira Ohishi* ${ }^{*}$, M.D. \\ Kevin A. Schulman*, M.D.
}

\begin{abstract}
Economic analysis of new medical therapies and new medical technologies is an increasingly important endeavor worldwide. Pharmacoeconomic research should be conducted not only by pharmaceutical companies but also by academic investigators. However, in the current environment, manufacturers are the sponsors of most economic evaluations of their products. This sponsorship can lead directly to the potential for conflicts of interest or bias in study design or results. However, this potential for bias can be managed by carefully defining the relationship between investigators and sponsors (investigator independence and independent publication rights), and by financial disclosure policies by journals. Further, the development of high-quality economic data from clinical trials removes many potential sources of bias that exist in the construction of economic models. In this paper, we introduced and reviewed several efforts to develop guidelines for conduct of economic studies to improve the quality of the economic literature: the New England Journal of Medicine's policy on cost-effectiveness analysis; the Task Force on Principles for Economic Analysis of Health Care Technology's voluntary ethical guidelines; and the FDA's draft guidelines that concern promotional claims and standards of evidence for comparative research which should be of interest to the Japanese audience. If it is to be useful for policy-makers, economic data must be credible and reliable. We must strive to create a system where manufacturers have an interest in unbiased assessment of their products to promote a truly competitive marketplace for pharmaceutical products.
\end{abstract}

Key Words : Pharmacoeconomics, Sponsor researcher relationship, Guideline, Bias

\footnotetext{
* Clinical Economics Research Unit, Department of Medicine,

Georgetown University Medical Center

$\dagger$ Kasumigaura National Hospital as of April 1998
} 


\section{Introduction}

Several countries have adopted formal guidelines for economic evaluation of new pharmaceutical products. Australia has implemented a set of national guidelines that mandate the presentation of pharmacoeconomic data at the time of product registration in order for the products to qualify for reimbursement through the national health insurance systems ${ }^{1,2)}$. In many European countries, submission of economic data is encouraged ${ }^{3)}$, and has recently been mandated in Denmark ${ }^{4)}$. Several major organizations that run trials, such as the UK Medical Research Council (MRC) and the European Organization for Research and Treatment of Cancer (EORTC), have policies of considering health economics and quality-of-life implications when a new randomized clinical trial is designed. These policies have fostered efforts to integrate economic evaluation and economic concepts into the clinical development process. In Japan, pharmaceutical companies have been submitting post-adoption pharmacoeconomic data to the government in recent years ${ }^{5)}$. In fact, a Medline literature search, using keywords "randomized clinical trials", "cost-effectiveness", and "prospective study" demonstrated that the total number of pharmacoeconomic studies on clinical trials and the number of prospective economic analyses alongside clinical trials (phase III or IV) have been increasing year by year throughout the 1990's (Figure 1).

At the same time that policy makers are becoming more aware of the importance of economic information in technology assessment, analysts have focused on the need to improve the rigor of the analyses to ensure their applicability to health policy decision making.

The focus on economic evaluation has entailed two distinct efforts. The first is related to the quality of the methods for economic evaluation. This effort has resulted in a proliferation of significant methodologic books and manuscripts designed to assess the theoretical and practical applications of economic assessment $t^{6-9}$. The second focus is related to the quality of the information itself given the potential for bias in assessing and reporting study results ${ }^{10,11}$. Audiences may not believe that all results, including ones potentially unfavorable to their sponsors, will be published. Further, some pharmaceutical manufacturers may consider results of pharmacoeconomic studies promotional but not scientific information.

Although some economic analyses in the United States are sponsored by the Agency for Health Care Policy and Research (AHCPR), the National Institute of Health (NIH), and other neutral sources, the majority are funded by companies that hope these analyses will put their products in a favorable light ${ }^{11}$. The Wall Street Journal recently reported growing concerns about the reliability of pharmacoeconomic studies financed by drug manufacturers ${ }^{12)}$. Since the sponsors of pharmacoeconomic studies have a large economic interest in research outcomes, and since researchers conduct pharmacoeconomic studies under pressure from these for-profit sponsors, the potential for bias is inherent in such a structure ${ }^{2.10)}$. Sometimes, results may be unfavorable for the pharmaceutical companies due to poor patient outcome with use of their products. If these unexpected results were not published, publication bias would ensue. As a result, evidence-based medicine could not be established ${ }^{13}$.

The potential for bias in medical research is not a new phenomena, and is not limited to 
Fig. 1 The Yearly Number of Articles of CEA in Randomized Controlled Trials : Number of Total and Prospective Study

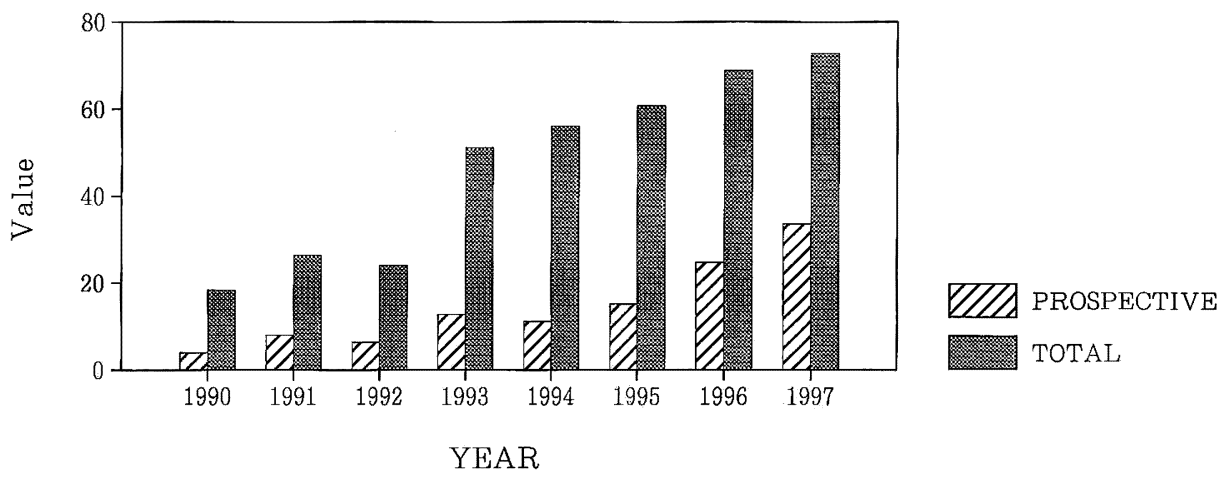

From searching Medline using Cost-effectiveness study, and RCT.

economic research. Problems arise out of conflicts of interest between the researcher's (and possibly institution's) academic interests and financial interests when objectivity, truth telling, and disclosing results of research, all of which are essential to scientific rigor and integrity, are compromised by the desire for greater reward ${ }^{14,15)}$. Given the nature of research studies, investigators must make many decisions about the study question, the study design, the analytic method, and the final data presentation. The concern is that potential conflicts of interest may result in opportunities for bias in the development and presentation of pharmacoeconomic study results either overtly, or subtly through decisions made by the investigators at any stage of the study. Others have reported that if investigators have personal financial connections to companies, it is more possible that biased or entirely withheld publications ensue ${ }^{16-22)}$. Economic evaluation has been thought to be particularly susceptible to these factors since the methods for economic evaluation are not as well established as those for clinical studies.

Guidelines safeguarding against bias should also apply to biomedical research ${ }^{23-26)}$. The non-steroidal anti-inflammatory drugs used in the treatment of arthritis tested by manufacturers have almost always reported as being equal or superior in efficacy and when compared to nonsteroidal anti-inflammatory drugs produced by their competitors. These claims of superior performance, especially with regard to side effect profiles, are often not supported by trial data $^{25)}$. Recently, the effects of financial conflicts of interest were examined using a mail questionnaire regarding articles on the controversy surrounding the safety of calcium-channel antagonists ${ }^{26)}$. Authors who supported the use of calcium-channel antagonists were significantly more likely than neutral or critical authors to have a financial relationship with the manufacturers of calcium-channel antagonists. The results of the questionnaire suggest that the medical profession needs to develop a more effective policy on conflict of interest. The results also support the complete disclosure of any relationships between pharmaceutical manufacturers and clinicians and researchers who write articles examining pharmaceutical products.

If biased results are published or remain unpublished because they are unfavorable or 
negative, patients will suffer poor quality health care and society will be troubled by the inefficient allocation of scarce health care resources. If the investigators do not publicize the truth, they will help physicians unconsciously violate nonmaleficence, or the duty of health care providers to do no harm both medically and economically, one of the four principles of biomedical ethics ${ }^{22.28)}$. Even if patients can choose their therapy, without enough scientific information there will be a mere shell of autonomy (the right of patients to make choices regarding their health care, another principal of biomedical ethics). The results of economic analyses should be used not only for the profit of pharmaceutical companies but also for benefits to audiences (decision-makers, insurance companies, physicians, and patients) who seek reliable and reproducible pharmacoeconomic studies.

Bias in industry-academic partnerships may stem in part from the lack of necessary independence for researchers. One possible means for avoiding bias is to carefully manage the potential for conflicts of interest by study investigators. One such protection is a sponsored research agreement defining the responsibilities and the rights of the parties in the collaborative research relationship ${ }^{11}$. In the biomedical field, a variety of organizations, such as the American Medical Association ${ }^{29)}$, the American Federation for Clinical Research ${ }^{30)}$, the Association of American Medical Colleges ${ }^{31}$, and a number of medical schools, have developed guidelines on investigator conduct or are proposing regulations to minimize potential conflicts of interest in clinical research ${ }^{11)}$. Another means of avoiding bias is to improve the quality of the study methods. For example, primary economic data collection may offer reduced opportunities for bias compared with development of economic models.

In this paper, we introduce several efforts to develop guidelines for conduct of economic studies : the New England Journal of Medicine's policy on cost-effectiveness analysis ${ }^{32}$; the Task Force on Principles for Economic Analysis of Health Care Technology's voluntary ethical guidelines $^{33)}$; and the FDA's draft guidelines that were issued mainly for pharmaceutical companies $^{34-36)}$. Lastly, we present examples of manuscripts based on adherence to these guidelines. We then make several suggestions to develop policies regarding bias in sponsored research for Japan.

\section{Guidelines for pharmacoeconomic studies}

\section{1) The New England Journal of Medicine's policy on cost-effectiveness analysis}

The New England Journal of Medicine recently described its policy on the publication of cost-effectiveness analysis using secondary data sources ${ }^{32}$. Basically, the Journal decided to treat these articles as editorials, and to hold them to the same standards as already established for this category of articles. When a cost-effectiveness analysis is submitted for publication, the journal expects its authors to provide information that will allow the editors to judge whether or not an incentive for bias exists. The incentive for bias is measured by three conditions. First, any study supported by industry must be funded by a grant to a not-forprofit entity such as a hospital or a university, and not to an individual or group of individuals. Journal editors are not going to review cost-effectiveness studies if any study author receives a direct salary from the sponsoring company or a competing company. The journal also 
excludes authors with an equity interest in, an ongoing consultancy with, or a membership on the scientific advisory board of such a company, or a related patent pending.

Second, the editors must receive written assurance that the agreement between the authors and the funding company ensures the authors' independence in the design of the study, the interpretation of data and writing of the report, and decisions regarding publication, regardless of the results of the analysis. The investigators must retain access to the data. Third, to ensure that the analysis can be assessed or replicated by reviewers and readers, the manuscript must include all the data used in the analysis and all of the assumptions upon which the data are based. There must be a clear explanation of the assumptions used in building the model. These conditions aim to provide a stronger restriction than disclosure requirements applied to other forms of original research.

This policy statement outlines a specific framework for relationship between sponsors and investigators for secondary economic studies. This framework includes several specific steps to protect the independence of investigators and to attempts to ensure submission of unbiased analyses to the Journal.

\section{2) Voluntary ethical guidelines by the Task Force on Principles for Economic Analysis of Health Care Technology}

Faculty at the Leonard Davis Institute at the University of Pennsylvania organized the Task Force on Principles for Economic Analysis of Health Care Technology to develop voluntary ethical guidelines for the sponsorship of cost-effectiveness analysis. The task force was sponsored by pharmaceutical companies and included academics and representatives from pharmaceutical industry, the public sector, and private research organizations ${ }^{33}$. It issued guidelines both for researcher independence and for reporting economic outcomes research in the Annals of Internal Medicine.

The task force guidelines include recommendations for study design, control of and access to data, project control, reasons for study termination, financial relationships between sponsors and researchers, disclosure, conflict of interest, pilot and feasibility studies, data analysis and reporting, publication and dissemination issues, and authorship in guidelines for researcher independence. Unlike the policy of the New England Journal of Medicine on cost-effectiveness analyses $^{32}$, these guidelines do not exclude researchers who are either employed by or have an ongoing financial relationship with a sponsor, such as a consultancy or stock ownership. They do not prohibit personal reward for investigators within the real costs of the research. Therefore, the guidelines for researcher independence by the task force are less strict than the policy of the New England Journal of Medicine. The guidelines recommend that a description of any financial arrangement between sponsor and investigator that might result in a potential conflict of interest be published as part of standard disclosure when articles are submitted. According to the task force, economic research will be more credible if conducted under generally accepted norms for the independence of researchers. Should questions arise regarding the validity or reliability of original analysis, the guidelines recommend that research teams should retain access to raw data in order to do a reanalysis.

Again, these guidelines relate to relationship between investigators and sponsors of 
economic evaluation. However, these recommendations reduce restrictions on investigators in undertaking economic assessments.

\section{3) Sponsored Research Agreement}

Relationships between sponsors and investigators in pharmacoeconomic and clinical research were discussed in a recent review ${ }^{11)}$. In this paper, the authors proposed creating research agreements to clarify the respective roles and responsibilities of the sponsors and the research institutions, to ensure the scientific integrity of pharmacoeconomic studies. The discussion focuses primarily on the rights of the investigators which fall into 6 areas: publication, or the mutual rights of researchers and sponsors to independently analyze and publish the findings of a study regardless of the outcome; specification of analysis, or the right to develop an initial and a final analysis plan in order to help mediate potential conflicts of analysis; data access/ownership, or the right to retain access to the data for noncommercial research and educational purposes; confidentiality, or the right to have access to the data collection instruments or data elements, or to publish the results of the study despite the confidentiality provision; termination, or the right to continue the study despite early negative results; and payment to investigators, or the right to receive study budgets based on the effort required by investigators to accomplish the goals of the study ${ }^{11}$. They also developed a draft of such an agreement to serve as a model contract for investigators and sponsors. This paper again reviews relationships between investigators and sponsors to govern roles and responsibilities in conducting economic evaluations.

\section{4) The FDA's draft guidelines}

In 1995, the FDA's Division of Drug Marketing, Advertising, and Communications (DDMAC) issued draft guidelines for reviewing pharmacoeconomic claims for promotional purposes $^{34}$. DDMAC is responsible for review of drug promotion in the United States. DDMAC review exists separately from the drug approval process, and review occurs only after products are marketed. These guidelines do not apply to the conduct, analysis or reporting of those pharmacoeconomic studies intended to serve as a basis for scientific exchange. Rather, this set of principles focuses on the nature and degree of substantiation and the types of disclosure necessary to support the use of pharmacoeconomic claims in pharmaceutical promotion.

In short, the guidelines stipulate the following conditions. Pharmacoeconomic claims should be compatible with existing rules that prohibit 'false and misleading promotion' and must be 'consistent with, and not contrary to, approved product labeling'. Comparative pharmacoeconomic claims, including cost-effectiveness and quality-of-life claims, are required to provide substantial evidence using two adequate and well-controlled studies including placebo, active, or historical controlled studies. Pharmacoeconomic studies are required to have scientific rigor, that is, an adequate level of precision (lack of random error) and validity (lack of systematic error), both internal (the validity of the inferences drawn as they pertain to the conditions of the study) and external (the validity of the inferences as they pertain to the conditions outside the study: generalizability). This should support the resulting claims and take into account both the positive and negative effects of the drug. The guidelines do 
state that studies must contain appropriate physical and monetary units and clearly state the perspective assumed in the study. Computer and mathematical models to provide estimations of pharmacoeconomic parameters should be used only when it is impractical or impossible to gather data using adequate and well-controlled studies. Intermediate health outcomes and quality-of-life measurements can be used only with evidence of scientific association to treatment endpoint. Study sources should be referenced and costs and discount rates should be explicitly cited. Sensitivity analyses should also accompany studies. Standards using international data must be applicable to the United States. When quality-of-life information is presented, studies should show evidence of the validity of the instrument and assume the patient's perspective. Claims that advertise a product's unconditional superiority must be based on studies that investigate all relevant comparators. Claims that promote equivalence in effectiveness or quality-of-life must be grounded in controlled clinical trials that not only show no statistical difference, but also possess the statistical power to detect such a difference. Price comparisons must be from the same (and referenced) source and compare equivalent doses or dosage forms. Promotional advertising also should include disclosures that discuss underlying assumptions, a description of the outcomes, the specific comparator used, and the overall limitations of the study ${ }^{34}$.

The FDA draft guidelines reflect several regulatory concerns. Most importantly, the FDA did not want manufacturers to have two types of claims based on differing levels of evidenceclinical claims and economic claims. Their proposed guidelines were an effort to ensure that manufacturers did not have an option to report claims using economic data rather than pursue the studies that would result in a clinical claim. Thus, the FDA proposed that manufacturers could not promote studies that include models of the long-term effect of drugs nor the use of published epidemiological data for lifetime projection which have been widely accepted by peerreview journals. The FDA prefers that data for the promotional use of pharmacoeconomic studies be produced only within the clinical trial setting. Therefore, the net effect of the FDA guidelines is to promote economic analyses alongside clinical trials. These draft guidelines currently control pharmaceutical manufacturer promotional activity even though they have not been finalized.

The Food and Drug Administration Modernization Act of 1997 added a new section to the Federal Food, Drug, and Cosmetic Act on health care economic information, or pharmacoeconomic claims. Under the statute, pharmacoeconomic data provided to a formulary committee by a medical products manufacturer will be considered in compliance and not false or misleading if this information 'directly relates to' an approved indication for the drug and is based on competent and reliable scientific evidence. Upon the FDA's request, the law does require that companies must produce data to substantiate their pharmacoeconomic claims. (The FDA announced that it did not intend to publish regulations for the part of the new statute affecting health economic claims. Instead, it plans only to issue 'interpretive guidance', which is a much faster and more informal process. Therefore, the 1995 draft guidelines will not be made final.) This legislation responded directly to the pharmaceutical industry's concerns that the FDA proposed rule on pharmacoeconomic studies was overly broad and anti-competitive. These guidelines govern the use of economic data, but do not make recommendations about the 
conduct of these evaluations or the relationship between investigators and sponsors.

\section{Summary}

In this section, we have reviewed several proposed measures to improve the quality of the economic literature. First, investigator independence and independent publication rights have been proposed to minimize the potential for conflicts of interest in study execution. Second, disclosure of sponsorship terms and financial relationships have also been proposed to minimize these conflicts. Third, economic data used should be held to the same scientific standards as clinical data both in development and presentation. Finally, readers must be made aware that no matter how well structured and regulated, research involves the potential for financial or other conflicts of interest and neither regulatory measures, peer-review, or independent investigators can guarantee that all research is unbiased ${ }^{26)}$.

\section{Case Studies}

In this section, we introduce four papers on economic analysis alongside clinical trials. Several of these studies have been recently reviewed. ${ }^{37)}$ We examine both the terms of the relationship between the sponsor and the researchers and the economic analyses presented. A questionnaire sent to the first authors by fax was used to provide data about study conduct for this inquiry.

\section{1) Results of the Economic Evaluation of the FIRST Study: A Multinational Prospective Economic Evaluation}

The study reports from a phase III clinical trial of epoprostenol, a potent vasodilator that was proposed for the treatment of patients with congestive heart failure ${ }^{38)}$. The study was stopped on recommendation by the study safety and data monitoring committee in July 1993 due to increased mortality in the epoprosterol-treated patients. The report, however, demonstrates the feasibility of collecting prospective economic data alongside phase III clinical trials.

Resource consumption and quality-of-life data were collected as an integral component of the clinical trial. Costs were developed from a societal perspective using a single US hospital. Outcomes were measured using the EuroQol instrument and the Nottingham Health Profile (NHP). Results of the survival analysis were reported in terms of quality-adjusted life-months (QALM). The NHP was used as a predictor in regression analyses predicting QALMs, as were variables describing patient characteristics and study site. In addition, the authors conducted two-tailed t-tests comparing average costs, days in the hospital, months of life, and QALMs for study and control patients. Because data were collected prospectively, the authors were able to construct $95 \%$ confidence intervals around reported results.

Results show that epoprostenol patients had costs $\$ 5,022$ greater than the costs for patients receiving usual care alone, excluding the costs of epoprostenol. Epoprostenol patients had no significant change in survival and had insignificantly lower quality-adjusted survival than 
control patients.

The authors conclude that although the study was clinically disappointing, the economic arm of the study demonstrates the feasibility of conducting an economic analysis alongside a phase III clinical trial.

The authors had a written agreement on mutual rights and responsibilities with their sponsor before they started their research. The sponsor did not require written approval of the manuscript before it could be submitted for publication. The sponsor had input into the design of their study including analysis methods and cost accounting. Both the economic data analysis and the clinical data analysis were conducted entirely by independent investigators. The researchers received the study budget only from the sponsor. The researchers could retain access to the raw data for reanalysis. Those economics researchers described the overall study as designed and conducted by both the sponsor and themselves. Further, this study illustrates that investigators can publish negative results of economic studies under sponsored research agreements.

\section{2) Prospective Economic Evaluation Accompanying a Trial of GM-CSF / IL-3 in Patients Undergoing Autologous Bone-Marrow Transplantation for Hodgkin's and Non-Hodgkin's Lymphoma}

This economic study was conducted alongside a randomized controlled phase III clinical trial that compared the efficiency of GM-CSF with Interleukin-3 (IL-3), a new cytokine therapy with that of a standard therapy, GM-CSF without IL-3, as supportive care in patients receiving autologous bone-marrow transplant for treatment of lymphoma ${ }^{\text {39) }}$.

Resource consumption and quality-of-life data were collected as an integral component of the clinical trial. Specifically, hospital and physician billing data for ABMT hospitalization at discharge and counts of utilized medical services were collected by monthly telephone interviews up to 13 months following discharge. Patients' use of medical services was recorded on a checklist, and was tracked by a monthly telephone interview. The economic analysis was performed from a societal perspective. Quality-of-life, a measurement of patient preferences for their health states, was measured every three months using the EuroQol thermometer, a visual analogue scale. The authors compared average costs, hospitalizations, rehospitalizations, outpatient resource consumption, months of life, and QALMs for study and control patients. Because data were collected prospectively, the authors were able to construct $95 \%$ confidence intervals around reported results.

Results show that the total cost estimates for patients receiving IL-3/GM-CSF $(\$ 89,651)$ were $\$ 9,759$ greater than those for patients receiving GM-CSF alone $(\$ 79,892)$. The total number of QALMs in the IL-3/GM-CSF (6.26 months) was 0.41 months smaller than that in GM-CSF alone (6.67 months). These differences were not statistically significant over the course of the study.

The authors conclude that although the study showed no significant effect of IL-3 on the costs of care for patients undergoing bone-marrow transplant for a period of up to 13 months after the procedure, the economic analysis does demonstrate the feasibility of prospective economic evaluation within phase III controlled clinical trials of new cancer therapies. 
The authors had a written agreement on mutual rights and responsibilities with their sponsor before they started their research. The sponsor did not require written approval of the manuscript before it could be submitted for publication. The sponsor had input into the design of their study including analysis methods and cost accouting. The clinical data analysis was conducted entirely by the sponsor, although the economic data analysis was conducted entirely by independent investigators. The researchers received the study budget only from the sponsor. The researchers could retain access to the raw data for reanalysis. The economics researchers described the overall study as designed and conducted by both the sponsor and themselves. Again, the investigators were able to publish an economic study that did not directly support the sponsor's product.

\section{3) Cost-effectiveness of simvastatin treatment to lower cholesterol levels in patients with coronary heart disease}

The study estimated the cost-effectiveness of lowering cholesterol levels with simvastatin in relation to the age, sex, and pretreatment cholesterol level of patients with coronary heart disease enrolled in a phase IV randomized clinical trial, the Scandinavian Simvastatin Survival Study (4S $)^{40)}$. All hospitalizations for cardiovascular causes were recorded for a period of more than five years in 4,444 patients. Their Markov model had 3 states: chronic stable state, temporary state by a coronary event, and death. They assumed that patients receiving simvastatin treatment did not incur additional costs for physician visits and laboratory tests, except the cost of the drug itself. Cost data for hospitalizations were based on patient-based cost-accounting systems at four Swedish hospitals that collected data for patients in various diagnosis-related groups. The costs of hospitalizations were estimated to include complications or coexisting conditions. Sensitivity analysis was used to test the robustness of the analysis to changes in several measured parameters.

The authors did not adjust quality-of-life measurements in order to estimate the number of quality-adjusted life months gained because they felt there were no valid quality-of-life weights to use for this assessment. They analyzed costs with and without productivity costs attributable to morbidity from coronary causes. Productivity costs were estimated by applying these estimates to the average annual cost for the labor of a full-time Swedish worker in 1995 $(\$ 35,300)$. Outcomes (cost per year of life gained) were measured using proportional hazard functions from $4 \mathrm{~S}$.

In the analysis limited to direct costs, results show that the costs of each year of life gained ranged from $\$ 3,800$ for 70 -year-old men with $309 \mathrm{mg} / \mathrm{dl}$ of cholesterol to $\$ 27,400$ for 35-yearold women with $213 \mathrm{mg} / \mathrm{dl}$ of cholesterol. With productivity costs, the results ranged from a net savings for the youngest patients to a cost of $\$ 13,300$ per year of life gained in 70-year old women with $213 \mathrm{mg} / \mathrm{dl}$ of cholesterol.

The authors conclude that simvastatin therapy is cost-effective among both men and women, 35 to 70 years of age, with total cholesterol levels 213 to $309 \mathrm{mg} / \mathrm{dl}$ in patients with coronary heart disease. However, this conclusion should not be extrapolated to apply to primary prevention, in which the absolute risks of coronary heart disease are substantially lower. 
The authors had a written agreement on mutual rights and responsibilities with their sponsor before they started their research. The sponsor did not require written approval of the manuscript before it could be submitted for publication. The sponsor did not have input into the design of their study including analysis methods and cost accouting. Both the economic data analysis and the clinical data analysis were conducted entirely by the independent investigators according to the researchers. The researchers received the study budget only from the sponsor. The researchers could not retain access to the raw data for reanalysis. Those researchers described the overall study as designed and conducted by the independent researchers.

\section{4) Cost-Effectiveness of Thrombolytic Therapy with Tissue Plasminogen Activator as Compared} with Streptokinase for Acute Myocardial Infarction

Mark et al used data from the GUSTO trial of tPA and streptokinase (SK) to assess the costeffectiveness of tPA in the treatment of acute $\mathrm{MI}^{41}$. One-year clinical data were based on the results of the 41,021-patient GUSTO trial. Life expectancy after one year was projected using data from the Duke Cardiovascular Disease Database. Resource consumption data were based on the initial hospitalizaiton for 23,105 US patients and from one-year follow-up data on a subsample of 2,600 US patients who had structured telephone interviews over a 12-moth period. Costs for these resources were developed from a hospital cost-accounting system and from Medicare reimbursement rates and were developed from the societal perspective. In their primary analysis, the authors assume that tPA results in no extra medical costs following the one-year endpoint of the clinical trial and that the survival benefit of tPA was still present following one year.

At the end of one year, tPA had both higher costs and a higher survival rate than SK. Discounting at 5\%, tPA had a marginal cost of $\$ 32,678$ per QALY gained as compared to SK. tPA was most economically effective in older patients and less so in younger patients.

Sensitivity analyses show that the cost-effectiveness ratios are sensitive to assumptions about life expectancy and medical costs for he tPA group after the first year. Results were robust to assumptions about the prevalence of stroke due to tPA.

The authors conclude that the cost-effectiveness of tPA falls within the range of other medical therapies currently accepted in the medical community.

The authors had a written agreement on mutual rights and responsibilities with their sponsor before they started their research. The sponsor did not require written approval of the manuscript before it could be submitted for publication. The sponsor had input into the design of their study including analysis methods and cost accounting. Both the economic data analysis and the clinical data analysis were conducted entirely by independent investigators. The researchers received the study budget partly from the sponsor. The researchers could retain access to the raw data for reanalysis. These researchers described the overall study as designed and conducted by the independent researchers. 


\section{Recommendations for Japan}

Pharmacoeconomic research should be scientific and must be reliable. In Japan, pharmacoeconomic research has recently been performed mainly by sponsors to submit the results to the Ministry of Health and Welfare ${ }^{5)}$. In the United States, these kinds of studies may be questioned if not subject to independent development and review. Pharmacoeconomic research should be conducted not only by pharmaceutical companies but also by academic investigators as in the United States or Europe as in the above cases. Several countries have established policies to ensure that submission to the government are unbiased or are constructed in a transparent fashion ${ }^{42,43}$. These types of measures may improve the quality of economic studies available to the Ministry of Health and Welfare in Japan.

In biomedical research in Japan, almost all studies supported by the pharmaceutical industry have been funded by a grant not only to a not-for-profit entity such as a hospital or a university but also to individuals or group of individuals. The persistence of this custom is unique, as it has been very problematic in other countries. A more fully developed grant mechanism to support investigator's research may also improve this practice. It is important to disclose all the financial relationship between the researchers and the sponsor as the Task Force recommends if the researchers received money from the sponsor personally or not ${ }^{33}$. The case studies presented have demonstrated that sponsors can work with independent academic investigators to design and implement economic studies, and that this is the state of the art in international pharmacoeconomics research.

Sponsored research agreements are ambiguous in most cases in Japan, because the agreements do not include details of the role and responsibilities in research. In some cases, research agreements simply state that the data should be used only for the research the sponsor and the investigators are planning at the time. In order to establish independence of investigators, detailed sponsored research agreements and protocols are required as in the four case studies above. The relationship between sponsors and researchers should be clarified as much as possible. If not, the results of pharmacoeconomic research performed by Japanese sponsors and researchers may not be accepted internationally and the development of pharmacoeconomics in Japan would be slowed.

In order to make pharmacoeconomic research more robust, Japan needs more health services researchers. Decision makers and physicians should also be able to understand the results of these studies and know if the results are biased or robust. Pharmaceutical companies also should have experienced health services researchers or foster their development. For this purpose, Japan should have programs of instruction in outcomes and effectiveness research at least in graduate schools. People in university, particularly in a medical school, and physicians should not be indifferent to the results of pharmacoeconomic research.

\section{Conclusion}

Economic analysis of new medical therapies and new medical technologies is an increasingly 
important endeavor worldwide. However, in the current environment, manufacturers are the sponsors of most economic evaluations of their products. This sponsorship can lead directly to the potential for conflicts of interest or bias in study design or results. However, this potential for bias can be managed by carefully defining the relationship between investigators and sponsors, and by financial disclosure policies by journals. Further, the development of highquality economic data from clinical trials removes many potential sources of bias that exist in the construction of economic models. If it is to be useful for policy-makers, economic data must be credible and reliable. We must strive to create a system where manufacturers have an interest in unbiased assessment of their products to promote a truly competitive marketplace for pharmaceutical products.

\section{References}

1. Laupacis A, Feeny D, Detsky AS, et al., How attractive does a new technology have to be to warrant adoption and utilization? Tentative guidelines for using clinical and economic evaluations, Can Med Assoc J, 146, 473-481, 1992.

2. Evans RG, Manufacturing consensus, marketing truth: Guidelines for economic evaluation, Ann Intern Med, 123, 59-60, 1995.

3. Fayers PM, Hand DJ, Generalisation from phase III clinical trials: Survival, quality of life, and health economics, Lancet, 350, 1025-1027, 1997.

4. Alban A, Gyldmark M, Pedersen AV, et al., The Danish approach to standards for economic evaluation methodologies, Pharmacoeconomics, 12, 627-636, 1997.

5. Ikeda S, Ikegami N, Oliver AJ, et al., A case for the adoption of pharmacoeconomic guidelines in Japan, Pharmacoeconomics, 10, 546-551, 1996.

6. Bootman JL, Townsend RJ, McGhan W, Principles of Pharmacoeconomics, 2nd ed., Harvey Whitney (Cincinnati), 1996

7. Gold MR, Siegel JE, Russell LB, et al., Cost-effectiveness in Health and Medicine, Oxford University Press (New York), 1996.

8. Drummond MF, O'brien B, Stoddart GL, et al., Methods for the Economic Evaluation of Health Care Programms, 2nd ed., Oxford Medical Publications (Oxford), 1997.

9. Brown M, Glick H, Harrell F, et al., Integrating economic analysis into cancer clinical trials, In Schulman KA, McCabe M, Brown M, eds., The NCI-ASCO Economic Workbook 1998, in press.

10. Hillman Al, Eisenberg JM, Pauly MV, et al, Avoiding bias in the conduct and reporting of costeffectiveness research sponsored by pharmaceutical companies, N Engl J Med, 324, 1362-1365, 1991.

11. Schulman KA, Rubenstein LE, Glick HA, et al., Relationships between sponsors and investigators in pharmacoeconomic and clinical research, Pharmacoeconomics, 7, 206-220, 1995.

12. Anders G, Doubts are cast on cost studies by drug makers, Wall Street Journal, Jun 28, Sect. B : 1(col.1), 1994.

13. Yee GC, Hillman AL, Applied Pharmacoeconomics: When can publication be legitimately withheld? Pharmacoeconomics, 12, 511-516, 1997.

14. Thompson DF, Understanding financial conflicts of interest, N Engl J Med, 329, 573-576, 1993.

15. Witt MD, Gostin LO, Conflict of interest dilemmas in biomedical research, JAMA, 271, 547-551, 1994.

16. Chalmers I, Underreporting research is scientific misconduct, JAMA, 263, 1405-1408, 1990.

17. Huth EJ, Irresponsible authorship and wasteful publication, Ann Intern Med, 104, 257-259, 1986.

18. Dickersin K, The existence of publication bias and risk factors for its occurrence, JAMA, 263, 1385-1389, 1990. 
19. Engler RL, Covell JW, Friedman PJ, et al., Misrepresentation and responsibility in medical research, N Engl J Med, 316, 1408-1409, 1987.

20. Goldfinger SE, A matter of influence, N Engl J Med, 316, 1408-1409, 1987.

21. Woolf PK, Ensuring integrity in biomedical publication, JAMA, 258, 3424-3427, 1987.

22. Relman AS, Dealing with conflicts of interest, N Engl J Med, 310, 1182-1183, 1984.

23. Davidson RA, Source of funding and outcome of clinical trials, J Gen Intern Med, 1, 155-158, 1986.

24. Gotzsche PC, Methodology and overt and hidden bias in reports of 196 double-blind trials of nonsteroidal anti-inflammatory drugs in rheumatoid arthritis, Control Clin Trials, 10, 31-56, 1989.

25. Rochon PA, Gurwitz JH, Simms RW, et al., A study of manufacturer-supported trials of nonsteroidal anti-inflammatory drugs in the treatment of arthritis, Arch Intern Med, 154, 157-163, 1994.

26. Stelfox HT, Chua G, O'Rourke K, et al., Conflict of interest in the debate over calcium-channel antagonists, N Engl J Med, 338, 101-106, 1998.

27. Beauchamp TL, Childress JF, Principles of Biomedical Ethics, Oxford University Press (Oxford), 1989.

28. Kimura R, Bioethics "Inochi wo kangaeru" Bioethics no susume, Nihon Hyoronsha (Tokyo), 1987.

29. Council on Scientific Affairs and Council on Ethical and Judicial Affairs, Conflicts of interest in medical center/industry relationships, JAMA, 263, 2790-2793, 1990.

30. American Federation for Clinical Research, Guidelines for avoiding conflict of interest, Clin Res, 38, 239240, 1990.

31. Guidelines for dealing with faculty conflicts of commitmentand conflicts of interest in research, Acad Med, 65, 485-495, 1990.

32. Kassirer JP, Angell M, The journal's policy on cost-effectiveness analyses, N Engl J Med, 331, 669-670, 1994.

33. Task Force on Principles for Economic Analysis of Health Care Technology, Economic analysis of health care technology : A report on principles, Ann Intern Med, 122, 61-70, 1995.

34. FDA, Division of Drug Marketing, Advertising, and Communications, Principles for the Review of Pharmacoeconomic Promotion (Draft Guidelines), 1995.

35. Food and Drug Administration Modernization Act of 1997, Conference Report submitted by Mr. Bliley. 105th Congress 1st Session, House of Representatives.

36. FDA proposes rules for drug benefit managers, Washington Post, January 9, A6, 1998.

37. Schulman KA, Linas BP, Pharmacoeconomics: State of the art in 1997, Annu Rev Public Health, 18, 529$548,1997$.

38. Schulman KA, Buxton M, Glick H, et al., Results of the economic evaluation of the FIRST study, Int J Technol Assess Health Care, 12, 698-713, 1996.

39. Schulman KA, Dorsainvil D, Yabroff KR, et al., the IL-3 Bone-MT Study Team, Prospective economic evaluation accompanying a trial of GM-CSF $/ \mathrm{IL}-3$ in patients undergoing autologous bonemarrow transplantation for Hodgkin's and non-Hodgkin's lymphoma, Bone Marrow Transplant 1998 ; in press.

40. Johannesson M, Jönsson B, Kjekshus J, et al., Cost effectiveness of simvastatin treatment to lower cholesterol levels in patients with coronary heart disease, N Engl J Med, 336, 332-336, 1997.

41. Mark DB, Hlatky MA, Califf RM, et al,, Cost effectiveness of thrombolytic therapy with tissue plasminogen activator as compared with streptokinase for acute myocardial infarction, $\mathrm{N}$ Engl J Med, 332, 1418-1424, 1995.

42. Ontario Ministry of Health, Ontario Guidelines for Economic Analysis of Pharmaceutical Products, Ministry of Health (Toronto), 1994 .

43. Commonwealth of Australia, Guidelines for the Pharmaceutical Industry on Preparation of Submissions to the Pharmaceutical Benefits Advisory Committee:Including Economic Analyses, Department of Health and Community Services (Canberra), 1995. 


\section{薬剤経済学研究の質をあげるために : バイアスを避けるためのガイドラインについて}

大 石

明

Kevin A. Schulman *

新しい治療法あるいは新しい医療技術の経済的分析は国を問わずますます重要な課題となってい る。薬剤経済学の研究は製薬会社のみでなくアカデミックな研究者によってあ行われるべきである。 しかし，現在の状況では自社製品の経済的評価をする場合，多くはその製薬会社がスポンサーとなっ ているのが実状である。このように自社がスポンサーになること自体, 研究者を私利私欲に走らせ る可能性があり研究方法や結果にバイアスを生じさせかねない。しかしながら，このようなバイア スは研究者とスポンサーとの関係を綿密に定義をすることにより対処可能である。またファーマコ エコノミクスの研究を揭載する雑誌が金銭関係を公表する方針を遵守することによっても回避する ことができる。さらに，臨床研究を用いた質の高い経済的分析のデータが生み出されれば，経済的 分析のためのモデルに伴いがちなバイアスを起こしうる多くの原因を除くことが可能である。本論 文では経済的分析を扱った論文の質を上げるために経済的研究のためのガイドラインを作成する試 みを紹介し分析する。一つはNew England Journal of Medicineの費用対効果 (cost-effectiveness）分析研究の投稿に対する方針である。あう一つはプロジェクトチームにより自発的にまた倫 理的に打ち出された医療技術の経済的分析における原則である。さらに企業の宣伝のための利用と 日本の利用者が興味を持つであろう比較研究のための証拠の基準に焦点を当てたFDAによるガイ ドラインの草稿についてあ解説した。政策に関わる人々にとって役に立つためには, 経済的データ は信用があり信頼できるものでなければならない。真に競争のある薬の市場を整えるためにも，わ れわれは製薬会社が自社製品のバイアスのかからない評価に興味を持てるような体制を作るよう努 カしなければならない。

キーワード : 薬剤経済学, スポンサーと研究者間の関係, ガイドライン, バイアス

*ジョージタウン大学医学部メディカルセンター臨床経済学研究所

†国立霞ケ浦病院内科（1998年 4 月現在） 